\title{
The distribution of Batrachochytrium dendrobatidis across the southern Appalachian states, USA
}

\section{Rollins AW ${ }^{1^{*}}$, Copeland $\mathrm{JE}^{\mathbf{1}}$, Barker $\mathrm{H}^{\mathbf{1}}$ and Satterfield $\mathrm{D}^{2}$}

\author{
${ }^{1}$ Department of Biology, Lincoln Memorial University, Harrogate, TN, 37752, USA \\ ${ }^{2}$ Union County High School, Maynardville, TN 37807, USA
}

Rollins AW, Copeland JE, Barker H, Satterfield D 2013 - The distribution of Batrachochytrium dendrobatidis across the southern Appalachian states, USA. Mycosphere 4(2), 250-254, Doi 10.5943/mycosphere/4/2/7

This study documents the occurrence of Batrachochytrium dendrobatidis (Bd) associated with the wood frog (Lithobates sylvatica) from the Cumberland Gap National Historical Park. This is the first report of Bd from the Park and subsequently from natural amphibian populations in the state of Kentucky. Based on the results of the current survey, a review of the literature, and records downloaded from the database maintained by BD-Maps.net, the following conclusions can be tentatively drawn: (a) the proportion of populations harboring $\mathrm{Bd}$ across southern Appalachian states appears to be relatively low, (b) mortality associated with $\mathrm{Bd}$ appears to be rare across the region, and (c) the highlands of the southern Appalachian mountains are notably under-sampled and understudied despite their conceivably high potential to contribute to our understanding of the factors predisposing populations to chytridiomycosis.

Key words - Chytridiomycosis - chytrid distribution - Cumberland Gap National Historical Park frogs - salamanders

\section{Article Information}

Received 27 January 2013

Accepted 14 March 2013

Published online 28 March 2013

*Corresponding author: Adam W Rollins - e-mail - adam.rollins@1munet.edu

\section{Introduction}

Batrachochytrium dendrobatidis $(\mathrm{Bd})$ is

a chytrid fungus capable of colonizing the epidermis of amphibians and can lead to a disease condition commonly referred to as chytridiomycosis (Berger et al. 1998). In some instances infected populations may experience high mortality rates. The origin, ecological affinities, mode of transmission, and the set of conditions by which the fungus becomes pathogenic are still rather poorly understood. However, some evidence suggests that other factors (e.g., anthropogenic effects, climate change, and pollution) may weaken amphibians thus predisposing them to the progression to chytridiomycosis (Pounds \& Crump 1994, Alford \& Richards 1999). Given the uncertainty of the conditions contributing to an apparent global decline in amphibians, Bd has recently been the subject of a substantial research effort worldwide. One fundamental aspect in elucidating the ecology of $\mathrm{Bd}$ is to develop a better understanding of its distributional patterns. Furthermore, it is imperative to identify those host populations that develop chytridiomycosis and document 
their associated historical, anthropogenic, biotic, and abiotic environmental variables. The objectives of the study reported herein were to (1) test for the presence of $\mathrm{Bd}$ in the Cumberland Gap area where the fungus had not yet been documented to occur and (2) determine the extent of previous sampling efforts as well as the documented occurrences of Bd across eight southern Appalachian states.

The Chytridiomycota represent a basal lineage of fungi that are characterized by producing flagella. Members of this group are common and sometimes abundant components of aquatic ecosystems where they play an important role in nutrient cycling through the decomposition of plant and animal detritus. However, in the case of $\mathrm{Bd}$, this species is capable of living in association with the epidermis of amphibians where it can persist as either a parasite or a pathogen. Susceptibility to $\mathrm{Bd}$ varies among individuals within a species, and among populations, and in many instances the disease condition, chytridomycosis, does not develop (Davidson et al. 2003). As such, some individuals or populations can function as reservoirs for the chytrid. In addition, it has been reported that at least some reptiles can function as reservoirs and or vectors for $\mathrm{Bd}$. For example, the presence of $\mathrm{Bd}$ in two lizard and three snake species were positively correlated with $\mathrm{Bd}$ occurrence among cooccurring anurans (Kilburn et al. 2011). Furthermore, simply the presence of $\mathrm{Bd}$ does not implicate the fungus as the cause of an amphibian decline or mortality event; as such, caution must be exercised in such an assessment (Daszak et al. 2005). The current investigation was initiated after the discovery of several dead wood frogs (Lithobates sylvatica) in a wetland within the Cumberland Gap National Historical Park, Kentucky, USA.

\section{Methods}

\section{Field Sampling}

During the 2009 field season four study areas were established in Tennessee and in 2010 an additional study area was established in the Cumberland Gap National Historical Park, Kentucky (Table 1). All specimens were captured using a scoop net, visually inspected for marks or lesions, and measured to determine the total body length. Each individual was handled with a clean pair of disposable latex gloves in order to reduce the potential for cross contamination.

Samples for the isolation of DNA were collected in the manner described by Pisces Molecular. In short, a sterile cotton swab was run across the dorsum, ventrum, left side, right side and the foot webbing five times each for a total of 30 strokes. The swab was immediately placed in a labeled $2.0 \mathrm{ml}$ screw-capped microcentrifuge tube containing $70 \%$ ethanol. The samples were then shipped to Pisces Molecular LLC for PCR analyses.

\section{Sampling Distribution Map}

Eight southern states (Alabama, Georgia, Kentucky, North Carolina, South Carolina, Tennessee, Virginia, and West Virginia) that intercept the Appalachian Mountain chain were selected as the area of interest. The results generated from the current study, a review of the literature, and database records downloaded from BD-Maps.net were used to construct a map elucidating the extent of $\mathrm{Bd}$ sampling among these southern Appalachian states. The GPS coordinates along with the host species sampled were recorded from these sources and divided into three classes (a) Bd not detected, (b) Bd detected no mortality reported, and (c) Bd detected mortality reported. A map was then generated using the freely available DIVA-GIS software package.

\section{Results}

\section{Field Survey}

Twenty-five specimens representing eleven species (eight anuran and three caudates) were obtained and swabbed from the Tennessee sites and all of these specimens tested negative for $\mathrm{Bd}$ (Table 2). Seventeen wood frog specimens were obtained from the Kentucky site. PCR analysis indicated that $33 \%$ of these samples were positive for $\mathrm{Bd}$. Interestingly, when these specimens were divided into small $(<5 \mathrm{~cm})$ and large $(>5 \mathrm{~cm})$ size classes, none of the specimens from the small size class were positive for $\mathrm{Bd}$, but $66 \%$ of those from the large size class were positive for $\mathrm{Bd}$. 
Table 1 General information pertaining to the study areas sampled.

\begin{tabular}{|c|c|c|c|c|}
\hline Site & Coordinates & Elevation (m) & State & County \\
\hline$S-1$ & $36.2835-83.8333$ & 457 & TN & Union \\
\hline S-2 & $36.2469-84.0993$ & 314 & $\mathrm{TN}$ & Campbell \\
\hline$S-3$ & $36.4413-83.5314$ & 441 & $\mathrm{TN}$ & Claiborne \\
\hline S-4 & $36.5801 \quad-83.6661$ & 430 & TN & Claiborne \\
\hline CUGA-1 & $36.6022-83.6922$ & 349 & KY & Bell \\
\hline
\end{tabular}

\section{Distribution}

Collectively the information gathered from the current survey, the review of the literature, and the records obtained from the BD-Maps database resulted in the identification of 150 sites within the eight states that have been surveyed for the presence of $\mathrm{Bd}$ (Fig. 1). Seventy-three percent of the sampled localities tested negative for $\mathrm{Bd}$, whereas $24 \%$ tested positive with no reports of mortality and the remaining $3 \%$ tested positive with reports of associated mortality. Overall, ten anuran and ten caudate species have been reported to harbor $\mathrm{Bd}$ from these eight states (Table 3). Mortality associated with populations harboring $\mathrm{Bd}$ in this region has been reported from only four species: wood frog, eastern newt (Notophthalmus viridescens), chorus frog (Pseudacris sp.), and an unidentified species of Lithobates; however, it is important to note that this does not necessarily implicate $\mathrm{Bd}$ as the causative agent.

\section{Discussion}

The current report of $\mathrm{Bd}$ associated with wood frogs from the Cumberland Gap National Historical Park is a new distributional record for this chytrid and to the best knowledge of the authors represents the first report from a natural amphibian population for Kentucky. Although mortality has been associated with this population, an attempt to determine if $\mathrm{Bd}$ was the causative agent was not undertaken as part of the current project.

The Appalachian Mountains particularly the highlands of Kentucky, North Carolina, Tennessee, and Virginia are seemingly under-sampled and relatively poorly known with respect to $\mathrm{Bd}$. Other studies, particularly those conducted in tropical regions (Puschendorf et al. 2006) and in the western United States (Muths et al. 2003) seem to suggest an increased potential for the development of chytridiomycosis in association with cool microenvironmental conditions. It is

Table 2 Summary of species collected during the 2009 and 2010 field surveys. Note "_" indicates negative for $\mathrm{Bd}$, "+" indicates positive for $\mathrm{Bd}$, and a blank space indicates that the species was not present from the site.

\begin{tabular}{llll}
\hline Species & Common Name & TN & KY \\
\hline Anurans & & - \\
\hline Anaxyrus americanus & American Toad & - \\
Anaxyrus fowleri & Fowler's Toad & - \\
Hyla versicolor & Gray Tree Frog & - \\
Lithobates catesbeiana & American Bullfrog & - \\
Lithobates clamitans & Green Frog & - \\
Lithobates palustris & Pickerel Frog & - \\
Lithobates sylvatica & Wood Frog & - \\
Scaphiopus holbrookii & Eastern Spadefoot Toad & \\
\hline Caudates & & - \\
\hline Eurycea bislineata & Northern Two-Lined Salamander & - \\
Eurycea longicauda & Long-Tailed Salamander & - \\
Eurycea lucifuga & Spotted-Tail Salamander & \\
\hline
\end{tabular}




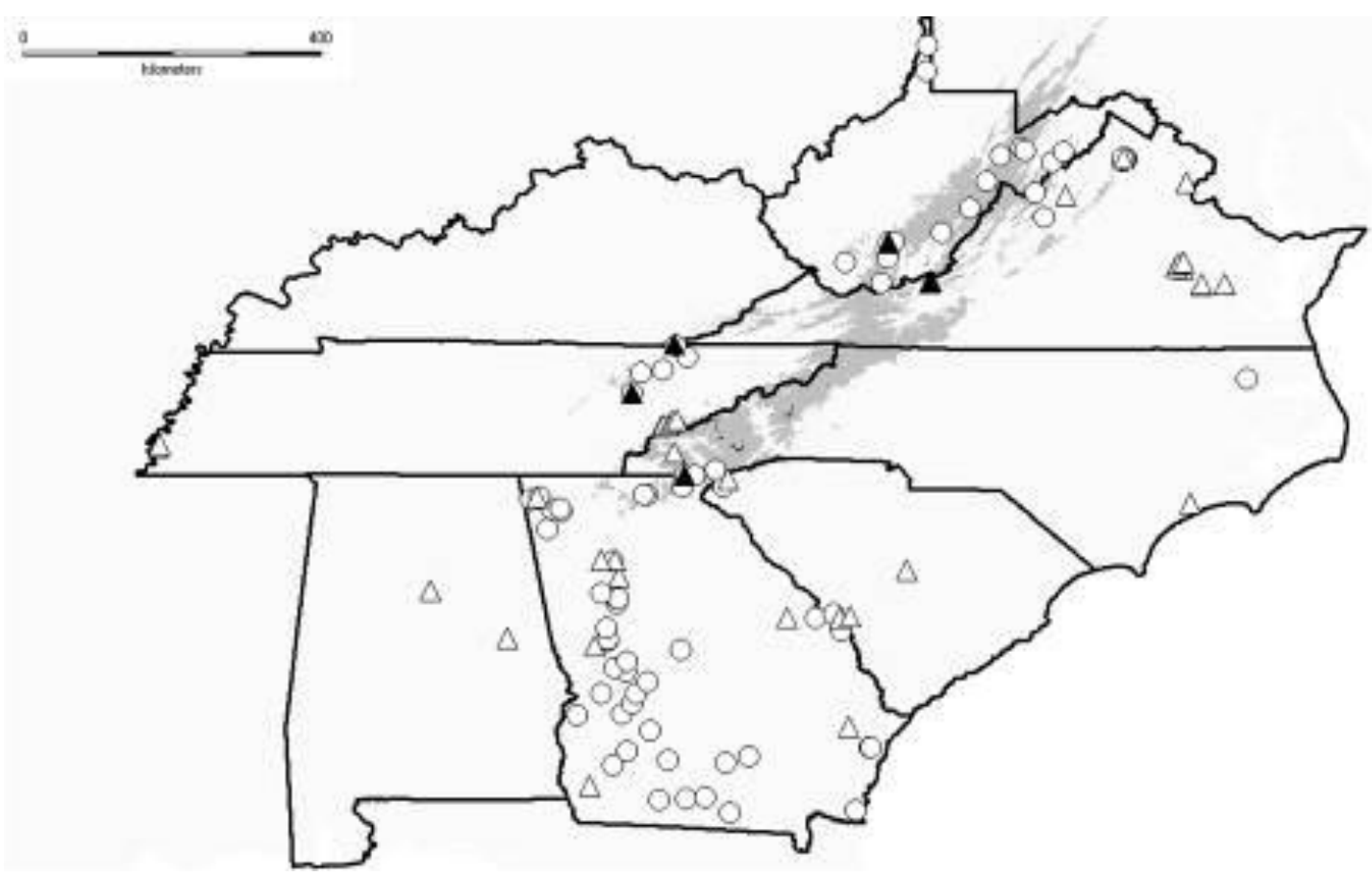

Fig.1 - The distribution of Batrachochytrium dendrobatidis surveys across the southern Appalachian states (USA) based on a review of the literature, BD-Maps.net, and the current survey. Open circles indicate a negative test for $\mathrm{Bd}$, open triangles indicate positive result for $\mathrm{Bd}$ and no mortality reported, and shaded triangles indicates positive result for $\mathrm{Bd}$ and mortality reported.

Table 3 Summary of the species reported to host Batrachochytrium dendrobatidis in the southern Appalachian states (USA) based on literature, BD-Maps.net, and the current survey. Note "+" indicates a positive test of occurrence and " $\mathrm{M}$ " indicates a positive test of $\mathrm{Bd}$ and reports of associated mortality.

\begin{tabular}{|c|c|c|c|c|c|c|c|c|c|}
\hline Species & Common Name & $\mathbf{A L}$ & GA & $\mathbf{K Y}$ & $\mathrm{NC}$ & SC & TN & VA & WV \\
\hline \multicolumn{10}{|l|}{ Anurans } \\
\hline Acris crepitans & Northern Cricket Frog & & & & & & & + & \\
\hline Anaxyrus sp. & Toad & & & & & & + & & \\
\hline Lithobates catesbeiana & American Bullfrog & & + & & + & + & & + & \\
\hline Lithobates clamitans & Green Frog & + & + & & & & & + & \\
\hline Lithobates heckscheri & River Frog & & + & & & & & & \\
\hline Lithobates palustris & Pickerel Frog & & + & & & + & + & & \\
\hline Lithobates sp. & & & M & & & & & & \\
\hline $\begin{array}{l}\text { Lithobates } \\
\text { sphenocephala }\end{array}$ & Southern Leopard Frog & & + & & + & + & + & + & \\
\hline Lithobates sylvatica & Wood Frog & & & M & & & + & & \\
\hline Pseudacris sp. & Chorus Frogs & & & & & & $\mathrm{M}$ & & \\
\hline \multicolumn{10}{|l|}{ Caudates } \\
\hline Desmognathus conanti & Spotty Dusky Salamander & & + & & & & & & \\
\hline Desmognathus monticola & Seal Salamander & & & & & & & + & \\
\hline $\begin{array}{l}\text { Desmognathus } \\
\text { quadramaculatus }\end{array}$ & Black-Bellied Salamander & & & & & & & & + \\
\hline Eurycea bislineata & Two-Lined Salamander & & & & & & & + & \\
\hline Eurycea cirrigera & $\begin{array}{l}\text { Southern Two-Lined } \\
\text { Salamander }\end{array}$ & + & & & & & & & \\
\hline Eurycea guttolineata & Three-Lined Salamander & & + & & & & & & \\
\hline Eurycea sp. & Lungless Salamander & + & & & & & & & \\
\hline $\begin{array}{l}\text { Notophthalmus } \\
\text { viridescens }\end{array}$ & Eastern Newt & + & + & & + & & + & M & \\
\hline Plethodon cinereus & Red Back Salamander & & & & & & & + & \\
\hline Pseudotriton ruber & Red Salamander & & & & & + & & & \\
\hline
\end{tabular}


interesting to note that the five localities in the southern Appalachian states that have reported mortality events are located within or near mountainous areas (Fig. 1). As such, the upland areas of the central and southern Appalachians would seem to represent an ideal opportunity to advance our understanding with respect to the ecology of $\mathrm{Bd}$. It would be particularly interesting to undertake an ecological survey that critically evaluates the occurrence of $\mathrm{Bd}$ and associated biotic and abiotic environmental parameters along a series of elevational transects.

Based on the available data, it appears that $\mathrm{Bd}$ occurrence in association with amphibians across this region is relatively low and accompanying mortality events are rare. However, this may simply represent an artifact of sampling efforts to date. For example, the highlands of West Virginia appear to be fairly well sampled (Fig. 1), but these localities are the result of a single study that only considered salamanders (Bartkus 2009). As such, a more widespread sampling effort across the region that encompasses several species of amphibians and reptiles needs to be undertaken in order to gain a clearer picture with respect to the ecology and distribution of Bd.

\section{Acknowledgements}

The authors wish to thank LMU undergraduates Brittany Barnes, Stefania Collins, and Shelby Baird for assistance with the literature search. This project was supported in part by the Lincoln Memorial University Department of Biology.

\section{References}

Alford RA, Richards SJ. 1999. Global amphibian declines: a problem in applied ecology.

Annual Review of Ecology, Evolution, and Systematics 30, 133-165.

Bartkus CJ. 2009. The occurrence of Batrachochytrium dendrobatidis in salamander populations of West Virginia. Master's Thesis, Marshall University. $80 \mathrm{pp}$.

Berger L, Speare R, Daszak P, Green DE, Cunningham AA, Gogin CL, Slocombe R, Ragan MA, Hyatt AD, McDonald KR, Hines HB, Lips KR, Marantelli G, Parkes H. 1998. Chytridiomycosis causes amphibian mortality associated with population declines in the rain forests of Australia and Central America. Proceedings of the National Academy of Sciences of the United States of America 95, 9031-9036.

Daszak P, Scott DE, Kilpatrick AM, Faggioni C, Gibbons JW, Porter D. 2005.

Amphibian population declines at Savannah River site are linked to climate, not chytridomycosis. Ecology 86(12), 3232-3237.

Davidson EW, Parris M, Collins JP, Longcore JE, Pessier, AP, Brunner J. 2003.

Pathogenicity and transmission of chytridomycosis in tiger salamanders (Ambystoma tigrinum). Copeia 3, 601607.

Kilburn VL, Ibanez R, Green DM. 2011. Reptiles as potential vectors and hosts of the amphibian pathogen Batrachochytrium dendrobatidis in Panama. Diseases of Aquatic Organisms 7, 127-134.

Muths E, Corn PS, Pessier AP, Green DE. 2003. Evidence for disease-related amphibian decline in Colorado. Biological Conservation 110, 357-365.

Pounds JA, Crump ML. 1994. Amphibian declines and climate disturbances: the case of the golden toad and the harlequin frog. Conservation Biology 8 , $72-85$.

Puschendorf R, Bolanos F, Chaves G. 2006. The amphibian chytrid fungus along an altitudinal transect before the first reported declines in Costa Rica. Biological Conservation 132, 136-142. 